\title{
Efektivitas Penggunaan Metode Reciprocal dan Demonstrasi Terhadap Teknik Dasar Shooting Sepakbola
}

\section{Effectiveness of Using Reciprocal and Demonstration Methods for Football Shooting Basic Techniques}

\author{
Oman Hadiana', Ridwan Luqmanul Hakim² \\ 1,2Prodi Pendidikan Jasmani Kesehatan dan Rekreasi, STKIP Muhammadiyah Kuningan, Indonesia \\ email: hadianaoman@upmkc.ac.id ${ }^{1}$, ridwanluqmanulhakim0232@gmail.com² \\ :https://doi.org/10.20884/1.paju.2021.2.2.3786
}

\begin{abstract}
Abstrak
Kemampuan teknik dasar shooting sepakbola yang ditunjukkan siswa kurang maksimal, seperti bola tembakan jauh dari sasaran, hasil tembakan mudah ditangkap penjaga gawang, dan bola tidak sampai ke gawang. Oleh karena itu diperlukan adanya solusi dengan mengaplikasikan metode pengajaran yang tepat. Tujuan penelitian adalah untuk mengetahui efektivitas penggunaan metode reciprocal dan demonstrasi terhadap teknik dasar shooting dalam permainan sepakbola. Metode penelitian menggunakan eksperimen desain the randomized pretest-posttest control group design. Subjek penelitian merupakan siswa kelas VIII SMP Negeri 1 Karamatmulya Kabupaten Kuningan dengan jumlah populasi sebanyak 182 orang, sedangkan sampel 60 orang yang dibagi menjadi dua kelompok. Kelas VIII A sebanyak 30 siswa diberi perlakuan metode resiprokal dan kelas VIII B sebanyak 30 siswa diberi perlakuan metode demonstrasi. Teknik pengambilan sampling yaitu cluster random sampling. Instrumen untuk mengukur keterampilan menembak bola dalam permainan sepakbola menggunakan tes shooting yang dikembangkan oleh Departemen Pendidikan dan Kebudayaan yang sudah valid. Teknik analisis data yang digunakan uji normalitas, uji homogenitas, dan uji independent sample $t$ test. Hasil penelitian menunjukkan metode reciprocal dan demonstrasi berpengaruh terhadap efektivitas teknik dasar shooting sepakbola, namun metode demonstrasi memberikan dampak yang lebih signifikan. Penelitian lebih lanjut diharapkan dapat mengkaji dengan menerapkan model pembelajaran kontemporer khusus untuk pendidikan jasmani dan olahraga dalam keterampilan bermain sepakbola.
\end{abstract}

Kata Kunci: Metode Pengajaran, Reciprocal, Demonstrasi, Shooting, Sepakbola

\begin{abstract}
The basic technique of shooting football shown by the students was not optimal, such as the ball shot far from the target, the result of the shot was easily caught by the goalkeeper, and the ball did not reach the goal. Therefore, a solution is needed by applying the right teaching method. The research objective was to determine the effectiveness of using reciprocal methods and demonstrations of
\end{abstract}

Alamat Koresponden : Prodi Pendidikan Jasmani Kesehatan dan Rekreasi, STKIP Muhammadiyah Kuningan

Email : hadianaoman@upmkc.ac.id

(c) (i)

Jurnal Physical Activity Journal (PAJU) This work is licensed under a Creative Commons Attribution 4.0 International License. 
basic shooting techniques in football. The research method used the experimental design the randomized pretest-posttest control group design. The research subjects were grade VIII students of SMP Negeri 1 Karamatmulya Kuningan Regency with a total population of 182 people, while the sample was 60 people who were divided into two groups. Class VIII A as many as 30 students were treated with reciprocal method and class VIII B as many as 30 students were treated with the demonstration method. The sampling technique was cluster random sampling. The instrument for measuring ball shooting skills in a football uses atest shooting validdeveloped by the Ministry of Education and Culture. The power analysis technique used normality test, homogeneity test, and independent sample $t$ test. The results showed that the reciprocal and demonstration methods had an effect on the effectiveness of basictechniques shooting football, but the demonstration method had a more significant impact. Further research is expected to be able to study by applying contemporary learning models specifically for physical education and sports in playing football skills.

Keywords: Teaching Methods, Reciprocal, Demonstration, Shooting, Football

\section{PENDAHULUAN}

Mencetak gol ke gawang lawan adalah tujuan utama dalam permainan sepakbola yang dapat menentukan hasil akhir dari pertandingan bagi salah satu tim kesebelasan. Lebih dari $70 \%$ gol tercipta dari sebuah tembakan (shooting), sehingga teknik dasar shooting ini sangat penting untuk diimplementasikan dalam sesi latihan/pembelajaran dengan program yang terukur (Triyudho, 2017). Shooting merupakan salah satu teknik dasar sepakbola yang harus dimiliki oleh setiap pemain. Secara teknis perkenaan bola saat menembak bola ke gawang bisa dilakukan dengan menggunakan punggung kaki, kaki bagian dalam, dan kaki bagian luar sesuai dengan situasi dan kondisi pada saat permainan berlangsung (Sucipto dkk, 2000).

Hasil temuan penelitian yang dilakukan (Pratama, 2017; Setiawan et al., 2018) menyatakan bahwa permainan modifikasi dapat meningkatkan keterampilan hasil belajar shooting sepakbola siswa. Penelitian lain menyatakan melalui implementasi model Team Games Tournament memberikan kontribusi positif terhadap teknik dasar shooting dalam permainan sepakbola siswa (Triyudho, 2017). Istofian \& Amiq (2016) menyatakan bahwa suatu metode yang tepat untuk meningkatkan teknik shooting dalam permainan sepakbola melalui metode drill (pengulangan).

Hasil pengamatan yang peneliti lakukan di SMP Negeri 1 Karamatmulya Kabupaten Kuningan mayoritas siswa kelas VIII masih kesulitan untuk menembak bola ke gawang lawan (shooting), terkadang perkenaan kaki ke bola kurang tepat, tumpuan tidak 
Oman Hadiana \& Ridwan Luqmanul Hakim | Efektivitas Penggunaan Metode Reciprocal dan Demosntrasi Terhadap Teknik Dasar Shooting Sepakbola

maksimal, pandangan terhadap sasaran tidak fokus sehingga mengakibatkan bola tidak masuk ke gawang (tidak terjadi gol). Permasalahan tersebut nampaknya harus segera diatasi karena dapat berimplikasi terhadap hasil belajar sepakbola yang kurang baik.

Berdasarkan hasil penelitian yang sudah dilakukan tentang beberapa model dan strategi pembelajaran untuk meningkatkan teknik dasar shooting dalam permainan sepakbola, tentunya masih banyak ruang dari penerapan metode yang tepat yang dapat meningkatkan efektivitas teknik dasar shooting dalam pembelajaran. Salah satu metode yang dapat digunakan untuk meningkatkan efektivitas shooting dalam permainan sepakbola adalah dengan menggunakan metode reciprocal dan demonstrasi.

Gaya resiprokal merupakan pengembangan dari gaya latihan untuk lebih menekankan adanya intensitas interaksi sosial dalam situasi pembelajaran dengan teman sebaya sehingga memunculkan feedback untuk segera ditindaklanjuti (Mosston et al., 2008). Gaya mengajar resiprokal yang digunakan dalam penelitian menekankan kepada siswa untuk berperan dalam hal pemberian tanggung jawab yang bergeser dari pelatih/guru ke teman sebaya dalam proses pembelajaran. Gaya mengajar resiprokal yang ditransformasi menjadi sebuah metode latihan memberikan siswa tanggung jawab untuk mengelola pembelajaran dengan adanya pergeseran peran seorang pelatih/guru ke teman sebaya. Dalam adegan peragaan tersebut siswa dibagi menjadi dua kelompok, ada siswa yang berperan sebagai pelaku, dan siswa lainnya sebagai observer (pengamat) untuk guru berfungsi sebagai fasilitator (Tamim, 2017).

Pengamatan yang dilakukan siswa terhadap temannya pada saat pembelajaran berlangsung, tentunya siswa harus memahami terlebih dahulu konsep pelaksanaan yang benar. Hal ini dikarenakan setiap siswa secara bergantian akan berperan sebagai observer sehingga siswa sebagai peran pelaku melakukan gerakan teknik keterampilan gerak (shooting dalam pembelajaran sepakbola) sesuai dengan tahapan yang benar (Tamim, 2017).

Pelaksanaan pembelajaran menggunakan gaya resiprokal, siswa sebaiknya memilki pemahaman dan teknik dasar terlebih dahulu, kemudian dilakukan dengan teknik lanjutan untuk memperhalus sebuah gerakan. Karakteristik dari implementasi metode resiprokal dalam pendidikan jasmani siswa terlebih dahulu harus memahami konsep dan mempelajari teknik gerak terkait dengan materi yang akan dipelajari (Tamim, 2017). Penelitian yang dilakukan (Kolovelonis \& Goudas, 2012) menguji keakuratan pencatatan 
siswa ketika mereka berlatih dengan gaya mengajar resiprokal dan evaluasi diri untuk mempelajari keterampilan chest pass dalam permainan bola basket. Secara umum, hasil penelitian menunjukkan bahwa rekaman siswa cukup akurat dengan kecenderungan melebih-lebihkan performa, dan keakuratan umpan balik yang diterima siswa berpengaruh positif terhadap performa chest pass mereka.

Selain menerapkan metode resiprokal dalam penelitian ini juga menerapkan sebuah metode demonstrasi untuk meningkatkan efektivitas shooting sepakbola. Hasil penelitian yang dilakukan oleh (Gultom, 2019) menemukan bahwa pemberian materi dengan menerapkan metode demonstrasi dapat meningkatkan kemampuan siswa dalam memahami materi, meningkatkan minat dan prestasi belajar siswa dalam materi passing bola voli. Penggunaan metode demonstrasi memberikan kesempatan kepada siswa untuk lebih banyak terlibat dalam aktivitas khususnya yang berhubungan dengan keterampilan motorik. Pengalaman belajar siswa secara langsung melalui demonstrasi akan menguatkan aspek pengetahuan yang diingat dalam waktu yang relatif lama dan keterampilan motorik secara terus menerus menuju tahap otomatisasi gerak (Panca Adi, 2018).

hasil penelitian lain yang telah dilakukan terkait penerapan metode demonstrasi dalam pembelajaran atletik secara langsung dapat menumbuhkan keberanian untuk melakukan aktivitas motorik (Winarko, 2020). Penelitian lainnya menjelaskan penerapan metode demonstrasi yang diberikan kepada siswa ternyata memberikan pengaruh yang signifikan terhadap peningkatan hasil belajar dribble bola basket siswa (Eto, 2013). Metode pengajaran demonstrasi merupakan penyajian materi ajar yang dikemas dengan cara memperagakan keterampilan, pengetahuan, atau sikap dalam sebauh proses yang dilakukan oleh guru itu sendiri atau bentuk tiruan lain sebagai sumber belajar yang diperlihatkan langsung kepada siswa (Huda, 2013).

Substansi dari penerapan metode demonstrasi memberikan kesan positif terhadap siswa karena mereka memperhatikan adegan keterampilan materi ajar secara langsung, sehingga membentuk pemahaman mendalam tentang tahapan gerakan dari awal sampai akhir pembelajaran. Selin itu siswa dapat melakukan pengamatan terhadap peragaan yang dipertunjukkan oleh guru selama proses pembelajaran materi shooting permainan sepakbola. 
Oman Hadiana \& Ridwan Luqmanul Hakim | Efektivitas Penggunaan Metode Reciprocal dan Demosntrasi Terhadap Teknik Dasar Shooting Sepakbola

Berdasarkan beberapa penjelasan hasil penelitian yang sudah diuraikan terkait dengan implementasi metode resiprokal maupun metode demonstrasi terhadap beberapa keterampilan motorik dalam mata pelajaran pendidikan jasmani, pada artikel ini penulis mengkaji, menerapkan dan membandingkan kedua metode tersebut untuk melihat pengaruhnya terhadap teknik dasar shooting sepakbola. Tujuan dari penelitian ini adalah untuk menguji penerapan metode resiprokal dan demonstrasi terhadap efektivitas teknik dasar shooting dalam pembelajaran sepakbola.

\section{METODE}

Jenis peneitian yang digunakan adalah metode eksperimen desain the randomized pretest-posttest control group design (Frankel, 2012). Konstalasi desain penelitian bisa dilihat pada tabel 1. sebagai berikut.

Tabel 1. Konstalasi Desain Penelitian

\begin{tabular}{lllll}
\hline Metode Demonstrasi & $R$ & $O$ & $X$ & 0 \\
\cline { 2 - 5 } Metode Resiprokal & $R$ & 0 & $C$ & 0 \\
\hline
\end{tabular}

Penelitian dilaksanakan di SMP Negeri 1 Karamatmulya Kabupaten Kuningan sebanyak empat kali pertemuan atas izin dari pihak sekolah sesuai dengan panduan kurikulum untuk materi permainan olahraga bola besar (sepakbola) ada empat tatap muka. Pelaksanaan penelitian mulai dari tanggal 4 sampai dengan 25 Februari tahun 2020. Populasi yang dijadikan subjek penelitian berjumlah 182 siswa kelas VIII terdiri dari enam kelas. Sedangkan sampel penelitian berjumlah 60 siswa, 30 siswa VIII A diberi metode reciprocal dan 30 siswa VIII B diberi metode demonstrasi. Teknik pengambilan sampling adalah cluster random sampling (Maksum, 2012).

Skenario pembelajaran untuk kedua kelas dilaksanakan dengan tahapan dan prosedur yang sama, yaitu diawali dengan kegiatan pendahuluan, inti, dan penutup. Hanya saja pada bagian inti pembelajaran baik metode resiprokal maupun metode demonstrasi mempunyai sintak tersendiri. Rangkaian pembelajaran shooting dalam permainan sepakbola dengan metode resiprokal siswa dibagi menjadi dua kelompok, satu kelompok sebagai pelaku (siswa/pembelajar), dan kelompok sebagai observer (pengamat) yang nantinya ada umpan balik (feedback) dari hasil pembelajaran.

Penerapan metode demonstrasi dilaksanakan dengan siswa mengamati, mencermati, serta mempelajari terlebih dahulu dari peragaan guru, siswa yang dianggap memiliki keterampilan shooting yang baik, atau dari media lainnya seperti rekaman video 
teknik dasar shooting. Dalam metode demonstrasi siswa mengamati secara langsung gerak spesifik peragaan teknik dasar shooting mulai dari perkenaan kaki ke bola, tumpuan kaki, pandangan terhadap sasaran (gawang), sehingga memudahkan siswa untuk meniru/mengikuti gerakan yang sudah diperagakan.

Materi shooting dalam pembelajaran sepakbola terdiri dari empat pertemuan, diantaranya pada pertemuan pertama siswa belajar teknik dasar shooting menggunakan kaki bagian dalam, pertemuan kedua shooting menggunakan punggung kaki, pertemuan ketiga shooting menggunakan kaki bagian luar, dan pertemuan empat kombinasi dari tiga pertemuan sebelumnya. Lebih jelasnya ilustrasi teknik dasar shooting dapat dilihat pada gambar dibawah ini:
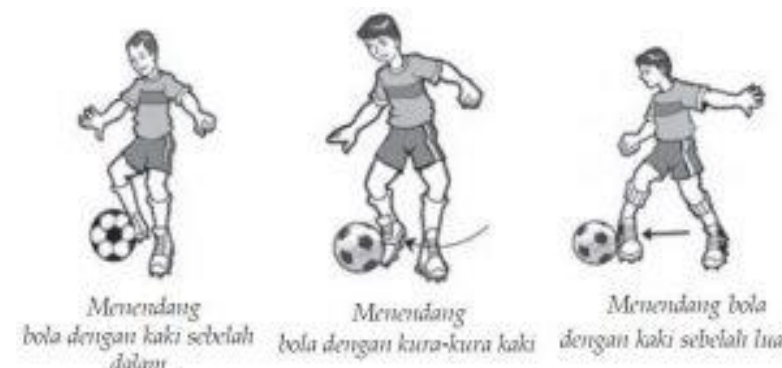
dalam

kola dengan kara-kara kaki dengan kakis sebetain tuar

Gambar 1. Teknik shooting dalam permainan sepakbola

Alat untuk mengukur teknik menendang bola (shooting) dalam sepakbola adalah instrumen tes shooting yang dikembangkan oleh Depdikbud dengan nilai validitas sebesar 0,876 dan nilai reliabilitas sebesar 0,946 (Efendi, 2019). Uji prasyarat analisis penelitian terdiri dari uji normalitas (kolmogorov smirnov) dan uji homogenitas (levene's test). Untuk menguji ada tidaknya perbedaan rata-rata antara kelompok metode resiprokal dengan metode demonstrasi menggunakan uji independent sample $t$ test (Gozali, 2013).

\section{HASIL}

Berdasarkan hasil analisis dan pengolahan data terdapat perbedaan hasil kelompok siswa yang menggunakan metode demonstrasi dengan resiprokal. Gambaran hasil analisis dapat dilihat pada tabel 2. dibawah ini.

Tabel 2. Hasil Posttest Metode Demostrasi dan Pesiprokal

\begin{tabular}{lccccc}
\hline & Metode & N & Mean & $\begin{array}{c}\text { Std. } \\
\text { Deviation }\end{array}$ & $\begin{array}{c}\text { Std. Error } \\
\text { Mean }\end{array}$ \\
\hline Shooting & Metode Demonstrasi & 30 & 8,00 & 2,244 &, 410 \\
\hline
\end{tabular}


Oman Hadiana \& Ridwan Luqmanul Hakim | Efektivitas Penggunaan Metode Reciprocal dan Demosntrasi Terhadap Teknik Dasar Shooting Sepakbola

\begin{tabular}{llllll}
\hline Sepakbola & Metode Resiprokal & 30 & 5,93 & 2,149 &, 392 \\
\hline
\end{tabular}

Berdasarkan tabel 2 dapat diinterpretasikan hasil tes akhir dari kedua metode pembelajaran demonstrasi dan resiprokal terdapat perbedaan. Nilai rata-rata untuk metode demonstrasi 8,00 sedangkan nilai rata-rata metode resiprokal 5,93. Dengan demikian metode demonstrasi memberikan pengaruh yang lebih baik dibandingkan dengan metode resiprokal terhadap shooting dalam permainan sepakbola. Adapun hasil pengujian independent sample $t$ test dari pengolahan data tes keterampilan shooting sepakbola untuk mengetahui perbedaan rata-rata antara dua kelompok yang menggunakan metode resiprokal dan metode demosntrasi terdapat pada tabel 3. sebagai berikut.

Tabel 3. Hasil Uji Independent Samples Test

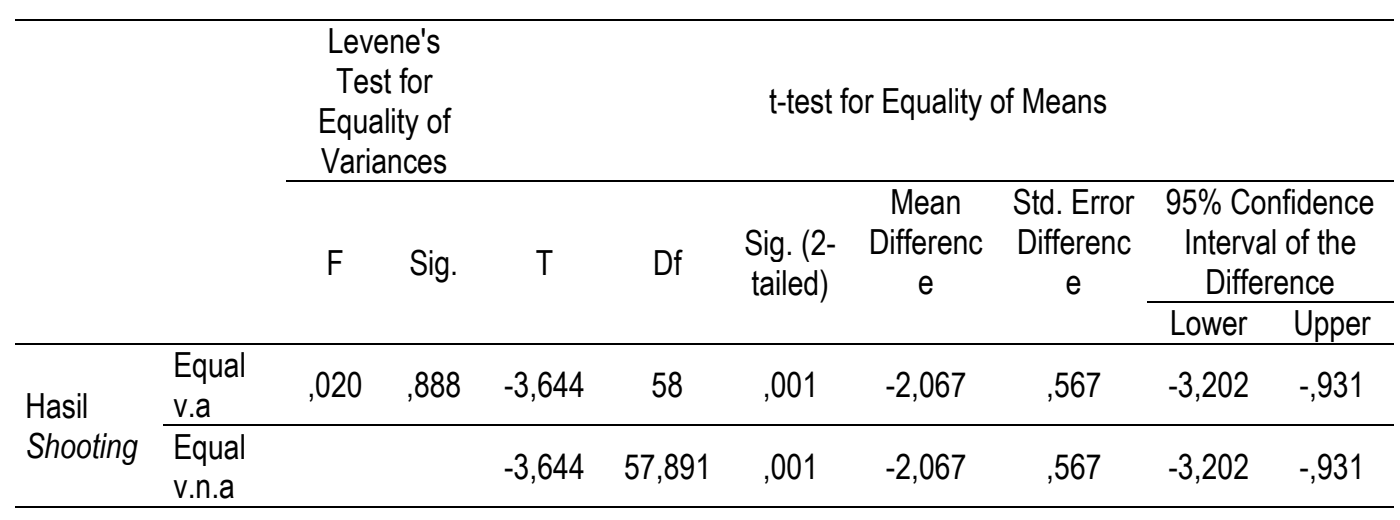

Dari data tabel diatas hasil perhitungan analisis independent samples t-test mengenai perbedaan pengaruh antara metode resiprokal dengan metode demonstrasi terhadap teknik dasar shooting sepakbola siswa di SMP Negeri 1 Karamatmulya Kuningan menunjukkan bahwa nilai Sig.(2-tailed) sebesar 0,001<0,05. Artinya terdapat perbedaan yang signifikan hasil teknik dasar shooting sepakbola menggunakan metode resiprokal dengan metode demonstrasi. Hal ini dapat dilihat pula dari nilai rata-rata kelas kedua metode pengajaran tersebut, dimana metode demonstrasi lebih tinggi dari metode resiprokal.

\section{PEMBAHASAN}

Temuan penelitian dari penerapan metode demonstrasi dalam pembelajaran sepakbola siswa memusatkan perhatian secara langsung terhadap model peraga terkait dengan implementasi teknik dasar shooting. Siswa mengamati secara langsung bagaimana tahapan melakukan shooting mulai dari sikap awalan, perkenaan kaki terhadap 
bola, tumpuan kaki, fokus pandangan terhadap sasaran sehingga siswa mempunyai gambaran yang utuh sebagai contoh untuk mereka peragakan dalam pembelajaran.

Role model dalam peragaan pada pembelajaran shooting sepakbola dilakukan oleh guru penjas, siswa yang dianggap terampil, dan dengan melihat tayangan audio visual. Hal tersebut selaras dengan apa yang dinyatakan oleh Roestiyah (2008) bahwa metode demonstrasi merupakan salah satu strategi mengajar dimana guru memperlihatkan peragaan tentang materi tertentu secara langsung kepada siswa, atau dilakukan oleh siswa yang dianggap mumpuni terhadap penguasaan materi sehingga memudahkan seluruh siswa mengamati untuk diaplikasikan oleh mereka tentang materi yang dipelajari.

Konsep metode demonstrasi dari pendapat lain yaitu sebagai salah satu strategi mengajar dengan cara menyajikan bahan ajar memperagakan keterampilan, pengetahuan, atau sikap oleh guru itu sendiri ataupun oleh sumber belajar lain secara langsung dihadapan seluruh siswa (Sadewa, 2015). Dalam proses pembelajaran guru merumuskan dengan jelas-jenis kecakapan atau keterampilan yang diperoleh siswa setelah demonstrasi shooting dilakukan. Kemudian menentukan peralatan yang digunakan untuk diuji coba terlebih dahulu agar pelaksanaan demonstrasi bisa meminimalisir kesalahan. Guru menjelaskan secara prosedural hal yang harus dilakukan, atau siswa terlebih dahulu melakukan percobaan shooting sebelum demonstrasi dilakukan. Guru memberikan kesempatan kepada semua siswa untuk melakukan teknik dasar shooting sepakbola, kemudian siswa merefleksi hal yang harus menjadi perbaikan dari gerakan yang sudah didemonstrasikan.

Penerapan metode demonstrasi dalam pembelajaran shooting sepakbola memberikan dampak yang signifikan, karena siswa melakukan gerakan didasarkan atas hasil dari mengamati contoh peragaan yang sebenarnya secara langsung. Temuan penelitian untuk metode resiprokal menunjukkan bahwa hasil belajar shooting siswa signifikan. Dalam metode resiprokal siswa diberi keleluasaan untuk melakukan gerakan teknik shooting berdasarkan pemahaman dan pengalaman sebelum diberikan materi, artinya instruksi pada metode ini siswa terlebih dahulu mempelajari bagaimana teknik dasar shooting ini dilakukan (Pamuji, 2013). Ketika siswa melakukan pembelajaran, ada siswa lainnya yang ditugaskan untuk mengamati (observer). Hal tersebut didukung dengan penelitian yang dilakukan Junaidi (2016) tentang gaya mengajar resiprokal mampu 
Oman Hadiana \& Ridwan Luqmanul Hakim | Efektivitas Penggunaan Metode Reciprocal dan Demosntrasi Terhadap Teknik Dasar Shooting Sepakbola

meningkatkan kreativitas siswa dalam pembelajaran praktik pendidikan jasmani dan olahraga.

Kreativitas nampak ketika adanya pembagian siswa sebagai pelaksana (belajar shooting sepakbola) dan siswa sebagai pengamat. Siswa sebagai pelaksana melakukan pembelajaran dengan memperhatikan tujuan pembelajaran yang sudah ditetapkan. Sedangkan tugas siswa sebagai observer mengamati jalannya proses pembelajaran yang dilakukan oleh siswa pelaksana sesuai dengan kriteria yang sudah dibuat sehingga ada feedback yang diterima tentang hasil dari sebuah gerakan shooting yang diperagakan. Dalam situasi proses pembelajaran berlangsung, feedback terjadi secara langsung antara observer dan pelaksana saling memberikan masukan dan evaluasi.

Shooting dalam permainan sepakbola merupakan bagian dari belajar gerak. Belajar gerak yang sistematis dan terstruktur akan memberikan hasil belajar yang optimal (Safitri et al., 2018). Penerapan metode resiprokal akan memberikan pengaruh signifikan terhadap efektivitas belajar shooting berdasarkan adanya suatu umpan balik dari teman sejawat terkait dengan hasil peragaan teknik yang diperagakan.

\section{SIMPULAN}

Metode pengajaran merupakan salah satu alat yang dapat digunakan untuk memudahkan siswa memahami dan menguasai keterampilan tertentu termasuk teknik dasar shooting dalam permainan sepakbola. Implementasi metode demonstrasi dan resiprokal memberikan pengaruh positif terhadap teknik dasar shooting dalam permainan sepakbola, dimana metode demonstrasi lebih dominan. Penelitian selanjutnya diharapkan dapat mengkaji tentang penggunaan suatu model pembelajaran kontemporer dalam pendidikan jasmani untuk mengembangkan keterampilan bermain sepakbola.

\section{REFERENSI}

Ali Maksum. (2012). Metodologi Penelitian dalam Olahraga. Surabaya: Unesa University Press.

Antep Anom Sadewa. (2015). Metode Pembelajaran Demonstrasi untuk Meningkatkan Kreativitas dan Hasil Belajar Musik Ansamble pada Siswa Kelas VII H di SMP Negeri 27 Semarang. Universitas Negeri Semarang.

Gozali, I. (2013). Aplikasi Analisis Multivariate degan Program IBM SPSS 21. Semarang: Badan Penerbit Universitas Diponogoro. 
Gultom, D. (2019). Penerapan Metode Demonstrasi dalam Upaya Meningkatkan Minat dan Prestasi Belajar Siswa pada Mata Pelajaran Pendidikan Jasmani Olahraga dan Kesehatan di Kelas VIII-1 SMP Negeri 1 Patumbak. Journal of Education and Teaching Learning, 1(1), 18-23.

Hepi Setiawan, Moch. Asmawi, \& W. (2018). Peningkatan Keterampilan Shooting Sepakbola Melalui Modifikasi Alat. KHAZANAH PENDIDIKAN: Jurnal IImiah Kependidikan, 12(1), 12-16.

Istofian, R. S., \& Amiq, F. (2016). Metode Drill Untuk Meningkatkan Teknik Menendang Bola ( Shooting ) Dalam Permainan Sepakbola Usia 13-14 Tahun. Kepelatihan Olahraga, 1(1), 105-113.

Jack R. Frankel., Norman E. Wellen., H. H. Y. (2012). How to Design and Evaluate Research in Education. In M. Ryan (Ed.), How to Design and Evaluate Research in Education (8th-ed ed., pp. 1-642). New York: McGraw-Hill.

Junaidi, J. (2016). Pengaruh Gaya Mengajar Resiprokal Dalam Pembelajaran Permainan Bola Voli Terhadap Pengembangan Kreativitas Siswa. Jurnal Pendidikan Jasmani Dan Olahraga, 1(1), 17. https://doi.org/10.17509/jpjo.v1i1.3660

Kolovelonis, A., \& Goudas, M. (2012). Students' recording accuracy in the reciprocal and the self-check teaching styles in physical education. Educational Research and Evaluation, 18(8), 733-747. https://doi.org/10.1080/13803611.2012.724938

Miftahul Huda. (2013). Model-Model Pengajaran dan Pembelajaran. Yogyakarta: Pustaka Belajar.

Mosston, M., Ashworth, S., \& Block, B. A. (2008). Teaching Physical Education. A Bell \& Howell Company.

Panca Adi, I. P. (2018). Pengaruh Metode Demonstrasi Berbantuan Bola Modifikasi Untuk Meningkatkan Aktivitas dan Hasil Belajar Passing Bolavoli Siswa SDN 1 Yahembang Kangin Tahun Pelajaran 2017/2018. Pendidikan Jasmani, Kesehatan, Dan Rekreasi Fakultas Olahraga dan Kesehatan, Undiksha, 8(2017). Retrieved from https://ejournal.undiksha.ac.id/index.php/JJP/article/view/14810/9077

Pratama, B. A. (2017). Meningkatkan Ketrampilan Shooting Sepakbola Dengan Permainan Modifikasi. Jurnal SPORTIF: Jurnal Penelitian Pembelajaran, 2(1), 48. https://doi.org/10.29407/js_unpgri.v2i1.655

Rahmat Pamuji. (2013). Pengaruh Gaya Mengajar Komando dan Gaya Mengajar Resiprokal terhadap Hasil belajar Chest Pass Permainan Bola Basket. Pedagogik, 1(1), 24-33. Retrieved from http://jurnal.unismabekasi.ac.id/index.php/pedagogik/article/view/1218/1085

Roestiyah. (2008). Strategi Belajar Mengajar. Jakarta: Rineka Cipta. 
Oman Hadiana \& Ridwan Luqmanul Hakim | Efektivitas Penggunaan Metode Reciprocal dan Demosntrasi Terhadap Teknik Dasar Shooting Sepakbola

Safitri, D. S., Mahendra, A., Budiman, D., Amelia, H., \& \& Supriatna, A. (2018). Peningkatan Keterampilan Gerak Lokomotor Melalui Penerapan Model Pendidikan Gerak Format Halang Rintang. Journal of Teaching Physical Education in Elementary, 1(2), 33-40.

Sucipto, Bambang Sutiyono, Indra M. Tohir, \& N. (2000). Sepakbola. Jakarta: Depdiknas.

Tamim, M. H. (2017). Pengaruh metode latihan (resiprokal dan inklusi) persepsi kinestetik terhadap teknik overhead lob forehand bulu tangkis. Jurnal Keolahragaan, 5(1), 71. https://doi.org/10.21831/jk.v5i1.12806

Tomi Manjela Eto, B. F. T. K. (2013). Perbandingan Penerapan Metode Demonstrasi Dan Metode Ceramah Terhadap Hasil Belajar Dribble Bola Basket. Jurnal Pendidikan Olahraga Dan Kesehatan, 1(2), 449-453.

Triyudho, R. (2017). Meningkatkan Pembelajaran Teknik Shooting dalam Permainan Sepakbola Menggunakan Model Pembelajaran Team Games Tournament Siswa Kelas X IPS 2 SMA Negeri 1 Kabewatan. KINESTETIK: Jurnal IImiah Pendidikan Jasmani, 1(1), 44-49.

Winarko, P. (2020). Upaya Meningkatkan Keberanian Aktivitas Siswa Kelas XI MIPA-2 Menggunakan Metode Demonstrasi pada Pembelajaran Pendidikan Jasmani Olahraga dan Kesehatan (Atletik) di SMA Negeri 1 Gambiran Banyuwangi. INCARE: International Journal of Educational Resources, 1(1), 38-44. Retrieved from http://ejournal.ijshs.org/index.php/incare/index

Yusuf Efendi, A. W. (2019). Uji Validitas dan Reliabilitas Instrumen Tes Shooting Sepakbola pada Pemain Tim Persiwu FC Jatiyoso. Jurnal Kesehatan Olahraga, 7(2), 367-372. 